\title{
KESADARAN MASYARAKAT TERHADAP HUKUM PERKAWINAN \\ DALAM PENERAPAN UNDANG-UNDANG NO 1 TAHUN 1974 TENTANG PERKAWINAN \\ (Studi Deskriptif pada Masyarakat Kelurahan Gombengsari Kecamatan Kalipuro Banyuwangi)
}

\author{
ZulfaMardiyatusSholeha ${ }^{1}$ Harjianto $^{2}$ \\ UNIVERSITAS PGRI BANYUWANGI \\ e-mail: zulfamardiya@gmail.com hr.bwin@gmail.com
}

\begin{abstract}
ABSTRAK
Perkawinan di bawah umur adalah perkawinan yang dilakukan oleh seorang pria dan seorang wanita yang usia keduanya masih di bawah batasan minimum yang diatur oleh Undangundang. Meskipun telah dijelaskan batas usia anak dapat melangsungkan perkawinan sesuai dengan Undang-undang perkawinan, masih banyak orang tua di pedesaan yang menikahkan anak perempuan pada usia 14-16 tahun.Tujuan dari penelitian ini adalah untuk mengetahuipemahaman masyarakat terhadap aturan dan hukum perkawinan yang sudah berkembang di masyarakat.

Metode yang digunakan dalam penelitian ini adalah metode penelitian kualitatif dengan pendekatan studi kasus. Data lapangan diperoleh dengan teknik observasi dan wawancara. Analisis data menggunakan analisis kualitatif, yaitu analisis yang memberikan deskripsi mendalam dan kesimpulan yang sesuai dengan topik dan tujuan dari penelitian. Adapun tahapan analisis data adalah tahap reduksi data, tahap penyajian data dan tahap analisis data. Hasil Penelitian ini menunjukan bahwa latar belakang masyarakat melakukan perkawinan di bawah umur yang terjadi di kelurahan gombengsari disebabkan oleh beberapa faktor diantaranya 1). Faktor ekonomi, 2). Faktor pendidikan, 3). Faktor orang tua, 4). Faktor lingkungan. Dari hasil penelitian juga menunjukan adanya dampak dari perkawinan di bawah umur diantaranya yaitu dampak positif, dampak negatif dan dampak terhadap hukum.
\end{abstract}

Kata kunci :Perkawinan, Masyarakat

\section{PENDAHULUAN}

Perkawinan merupakan tali ikatan yang melahirkan keluarga sebagai salah satu unsur dalam kehidupan bermasyarakat dan bernegara, yang diatur oleh aturan-aturan baik yang tertulis (hukum negara) maupun yang tidak tertulis (hukum adat).

Menurut Undang-undang No 1 Tahun 1974 pasal 1 yang berbunyi : Perkawinan ialah Ikatan lahir batin antara seorang pria dan seorang wanita sebagai suami isteri dengan tujuan membentuk keluarga (rumah tangga) yang bahagia dan kekal berdasarkan Ketuhanan Yang Maha Esa.

Dalam kompilasi Hukum Islam di Indonesia-inpres No 1 Tahun 1991 menguraikan bahwa pekawinan adalah pernikahan, yaitu akad yang sangat kuat atau miitsaaqan ghalidhan untuk menaati perintah alloh dan melaksanakannya merupakan ibadah.

Adapun Tujuan perkawinan menurut Undang-undang Perkawinan No 1 Tahun 1974 adalah untuk membentuk keluarga (rumah tangga) yang bahagia dan kekal berdasarkan Ketuhanan Yang Maha Esa.

Dalam Undang-undang Nomor 1 Tahun 1974 ditentukan juga batas usia minimal untuk melangsungkan perkawinan. Ketentuan mengenai batas usia minimal tersebut terdapat di dalam Pasal 7 ayat (1) Undang-undang Nomor 1 Tahun 1974 yang mengatakan bahwa " Perkawinan hanya diijinkan jika pihak pria sudah mencapai 
usia 19 tahun dan pihak wanita sudah mencapai usia 16 tahun".Dari adanya batasan usia ini dapat diartikan bahwa Undang-undang Nomor 1 Tahun 1974 tidak menghendaki pelaksanaan perkawinan di bawah umur yang telah ditentukan oleh Undang-undang Nomor 1 Tahun 1974.

Di masyarakat, sering kita dijumpai perkawinan di bawah umur, salah satu cara melakukannya dengan segaja memanipulasi atau memalsukan data kelahiran serta usia seseoang, dengan maksud agar dapat segera melakukan perkawinan. Kesadaran masyarakat terhadap hukum perkawinan sangat beragam. Mereka berpendapat bahwa usia untuk melakukan perkawinan adalah ketika anak-anak sudah mencapai aqil baligh, yang berarti ketika mereka sudah haid atau menstruasi merupakan bukti kebalighan-an seorang wanita. Mereka menganggap usia tersebut adalah usia siap menikah. Pemahaman tersebut dipengaruhi oleh beberapa faktor, yaitu: (1).Diantara mereka menganggap mengawinkan anak lebih cepat lebih baik. (2). Agar cepat lepas tanggung jawab orang tua biasanya lebih bersifat ekonomis. (3). Pelaksanaan Undangundang No 1 Tahun 1974 masih belum sepenuhnya berjalan dengan baik.

Berdasarkan hal tersebut, maka penulis tertarik untuk melakukan penelitian dengan judul "Kesadaran Masyarakat Terhadap Hukum Perkawinan dalam Penerapan Undang-undang No 1 Tahun 1974 Tentang Perkawinan di Kelurahan Gombengsari Kecamatan Kalipuro Kabupaten Banyuwangi".Dengan penelitian itulah diharapkan dapat mengetahui seberapa jauh kesadaran masyarakat terhadap hukum perkawinan dalam penerapan undang-undang no 1 tahun 1974 tentang perkawinan di bawah umur, yang pada akhirnya dapat membantu masyarakat untuk menekan angka perkawinan di bawah umur.

\section{METODE PENELITIAN}

Penelitian ini bertujuan untuk menggambarkan fenomena yang terjadi dalam masyarakat secara lebih detail dan terperinci pada kehidupan sosial tertentu. Penelitian deskriptif kualitatif ini merupakan metode penelitian yang menekankan pada kehidupan yang terjadi dalam kehidupan masyarakat.Penelitian ini menggunakan metode penelitian kualitatif deskriptif. Metode penelitian kualitatif adalah prosedur penelitian yang menghasilkan data deskriptif berupa kata-kata tertulis maupun lisan dari individu-individu atau perilaku yang diamatinya.

Teknik Pengumpulan Data yang digunakan peneliti yakni dokumentasi, wawancara, dan observasi. Dokumentasi yakni diperoleh dari interaksi bersama warga yang terlibat langsung dalam penelitian. Observasi yang dilakukan peneliti yakni observasi partisipan dimana peneliti terlibat dan datang langsung ditengah-tengah kegiatan responden. Dan wawancara dilakukan secara langsung dimana peneliti berhadapan langsung dengan narasumber dan menggunakan teknik wawancara tak terstruktur.

Analisis data yang digunakan dalam penelitian ini menggunakan model Miles and Huberman yang mengemukakan bahwa aktivitas dalam analisis data kualitatif dilakukan secara interaktif dan berlangsung secara terus menerus sampai tuntas, sehingga datanya sudah jenuh. Aktivitas dalam analisis data, yaitu data reduction, data display, dan conclusion drawing/verification.

Pengecekan Keabsahan Data merupakan uji kepercayaan terhadap data dan bertujuan untuk menguji kebenaran data atau informasi yng diperoleh. Dalam penelitian kualitatif dapat dilakukan dengan cara triangulasi. Triangulasi dalam pengujian kredibilitas ini diartikan sebagai pengecekan data dari berbagai sumber dengan berbagai cara, dan berbagai waktu. (Sugiyono, 2017: 189). Dengan demikian peneliti menggunakan triangulasi sumber.

Teknik triangulasi dalam penelitian ini dilakukan dengan cara membandingkan data antara hasil wawancara dengan observasi,hasil observasi dengan dokumentasi, serta hasil dokumentasi 
dengan hasil wawancara yang berkaitan dengan kesadaran masyarakat terhadap hukum perkawinan dalam penerapan undang-undang no 1 tahun 1974 tentang perkawinan di bawah umur.

\section{HASIL DAN PEMBAHASAN \\ PemahamanMayarakatTerhadapUndang -udang No 1 Tahun 1974}

Pemahaman masyarakat terhadap undang-undang no 1 tahun 1974 tentang perkawinan di bawah umur masih belum sepenuhnya mengerti mengenai undangundang perkawinan. Orang tua seringkali mendapat tekanan dari masyarakatnya untuk segera menikahkan anaknya terutama bagi anak perempuan, karena nilai-nilai sosial budaya memandang tugas utama perempuan adalah berumah tangga, di dapur, menjadi istri, mengasuh anak. Jadi perkawinan di pandang sebagai kewajiban sosial, dan bukan karena pertimbangan-pertimbangan lainnya. Atau untuk menghindari hubungan seks pranikah. Masyarakat seakan tidak mau tahu bahwa ada Undang-undang Perkawinan No 1 Tahun 1974 yang salah satu pasalnya yaitu pasal 7 yang menyatakan "perkawinan hanya diizinkan apabila pihak pria mencapai usia 19 tahun dan pihak wanita berusia 16 tahun".

Faktor-

\section{faktorMasyarakatMelakukanPerkawinan di bawahumur}

a. Faktor Ekonomi

Perkawinan di bawah umur terjadi karena keadaan keluarga yang hidup di garis kemiskinan, untukmeringankan beban orang tuanya maka anak wanitanya dikawinkan dengan orang yang dianggap mampu.

b. Faktor adat atau kebiasaan

Perkawinan yang disebabkan karena faktor adat adalah penerapan yang dilakukan secara turun temurun yang cenderung dengan cepat menikahkan anak perempuannya yang sudah baligh. Sedangkan laki-laki meskipunbelum mencapai usia 18 tahun apabila sudah mampu bekerja mencari nafkah atau berpenghasilan juga akan segera dinikahkan oleh orang tuanya.

c. Faktor pergaulan bebas

Karena kecelakaan yaitu karena pihak perempuan yang hamil terlebih dahulu sebelum menikah juga merupakan penyebab terjadinya perkawinan di bawah umur. Karena Tidak ada lagi jalan lain selain menikahkan anaknya.

d. Faktor keturunan

Faktor keturunan juga merupakan faktor utama penyebab terjadinya penerapan perkawinan di bawah umur. Anak yang menikah di bawah umur kemungkinan besar ibunya, neneknya dan nenek moyangnya juga menikah di bawah umur, kecuali bagi anak-anak yang menolak dengan alasan tertentu.

e. Faktor keinginan orang tua

Keinginan orang tua, baik karena usia mereka yang sudah tua maupun karena tersedianya biaya perkawinan.

\section{DampakdariPerkawinan di BawahUmur}

1. Dampak positif

Adapun dampak positif dari pernikahan dini adalah sebagai berikut: (1) Mengurangi beban ekonomi orang tua, karena dengan menikahkananaknya maka semua kebutuhan anak akan dipenuhi oleh suaminya,bahkan orang tua berharap beban ekonominya juga akan dibantu. (2). Mencegah terjadinya perzinaan di kalangan remaja, karena dengan menikahkan anak maka perbuata yang tidak baik seperti melekukan hubungan suami isteri sebelum menikah dapat di cegah, secara tidak langsung juga mencegah terjadinya hamil diluar nikah dikalangan remaja.

2. Dampak negatif

Adapun dampak dari perkawinan dini adalah sebagai berikut : (1) perselisihan yang menyangkut masalah keuangan yang terlampau boros, (2) dampak terhadap masing-masing keluarganya. (3) dampak bagi pasangan suami istri karena kurangnya pengetahuan yang didapat 
pasangan suami istri, akan menimbulkan pertengkaran sampai perceraian.

Berdasarkan hasil tersebut peneliti dapat menyimpulkan bahwa dampak dari perkawinan di bawah umur yaitu :

\section{Dampak positifnya}

Dampak positif dari perkawinan di bawah umur yang terjadi di kelurahan gombengsari yaitu : (1) dapat mencegah dari perbuatan zina (2) dapat mengurangi beban ekonomi keluarga.

2. Dampak negatifnya

Adapun dampak negatif dari perkawinan di bawah umur yaitu :

(1). Dampak terhadap pasangan suami istri yaitu dampak pada mental dan fisik yang belum matang dan belum siap untuk menghadapi kehidupan setelah perkawinan akibatnya masing-masing pihak ingin menang sendiri sehingga menyebabkan pertengkaran yang sampai berujung pada perceraian.(2). Dampak terhadap masing-masing keluarga, yaitu mereka masih mempunyai sifat kekanakkanakan dimana mereka masih belum bisa mandiri dalam mengurusi rumah tangga dan mereka masih akan merepotkan orang tua. (3). Dampak terhadap anak-anaknya, yaitu bagi mereka yang melangsungkan perkawinan di bawah usia 20 tahun apabila hamil akan mengalami gangguan pada kandungannya yang menyebabkan keguguran. Dan dampaknya juga mereka akan kehilangan masa mudanya karena mereka telah memutuskan untuk menikah di usia muda.

3. Dampak terhadap hukum

(1). Undang-undang No 1 Tahun 1974 Tentang Perkawinana yang dijelaskan dalam pasal 7 ayat 1 dan pasal 6 ayat.Pasal 7 ayat 1 yaitu , perkawinan hanya diijinkan apabila pihak pria sudah mencapai usia 19 tahun dan pihak wanita sudah mencapai usia 18 tahun. . Pasal 6 ayat 2 yaiu : untuk melangsungkan perkawinan seseorang yang belum mencapai usia 21 tahun harus mendapat ijin dari orang tua.
(2). Undang-undang No 23 Tahun 2004 Tentang Perlindungan Anak yang dijelaskan pada pasal 26 (1) orang tua berkewajiban dan bertanggung jawab untuk : (1) mengasuh, memelihara, mendidik, dan melindungi anak. (2) menumbuh kembangkan anak sesuai dengan kemampuan, bakat, dan minat. (3) mencegah terjadinya perkawinan di usia anak. (4) memberikan pendidikan karakter dan penanaman nilai budi pekerti pada anak.

\section{SIMPULAN}

Berdasarkan pembahasan hasil penelitian dan pada rumusan masalah maka dapat diambil kesimpulan sebagai berikut :

a. Pemahaman masyarakat kelurahan gombengsari mengenai Undang-undang No 1 Tahun 1974 Tentang Perkawinan di Bawah Umur sangat beragam yaitu.

1. Mayoritas mereka berpendapat bahwa mereka tidak mengetahui dengan undang-undang no 1 tahun 1974 tentang perkawinan dan ada pula yang hanya sebatas mengetahui namanya saja tapi tidak mengetahui apa isi dalam undang-undang tersebut.

2. Mereka menganggap bahwa usia perkawinan adalah ketika anak tersebut sudah mencapai baligh. Dimana jika laki-laki sudah terjadi mimpi basah dan suara yang mulai membesar, sedangkan pada perempuan biasanya ditandai dengan datangnya haid. Mereka menggapa usia tersebut adalah usia siap menikah.

3. Mereka menganggap menikahkan anak lebih cepat adalah lebih baik agar terjauh dari hal-hal yang negatif. Tidak adanya sanksi yang tegas dalam Undang-undang perkawinan. Pelaksanaan Undang-undang No 1 Tahun 1974 masih belum sepenuhnya berjalan dengan baik.

b. Latar belakang masyarakat melakukan perkawinan di bawah umur.

Perkawinan di bawah umur yang terjadi di kelurahan gombengsari disebabkan 
karena adanya faktor diantaranya sebagai berikut :

1. Faktor ekonomi, dimana keadaan ekonomi yang kurang mencukupi sehingga orang tua menikahkan anak pada usia yang masih terbilang anak-anak agar mengurangi beban orang tua.

2. Faktor pendidikan

3. Faktor orang tua, dimana mereka takut anak akan terjerumus ke hal-hal yang negatif

4. Faktor lingkungan

\section{DAFTAR PUSTAKA}

Akbar Nurhidayat.2013. Jurnal. Faktorfaktor penyebab perkawinan di bawah umur dilihat dari Hukum Islam dan Hukum Adat. Dikutip dari(https://www.google.com/search?q =faktor+faktor+prnyebab+perkawinan +di+bawah+umur+dilihat+dari+huku m+islam+dan+hukum+adat+oleh+nur hidayat+akbar+universitas+islam+neg $\underline{\text { ri+alaluddin }+ \text { makasar\&ie }=\text { utf- }}$ $\underline{8 \& o e=u t f-8}$ ) di akses pada tanggal 4 Juni 2018

Ananta Arya. 2013. Jurnal. Analisis Perkawinan Anak di Bawah Umur Tinjauan Hukum Islam dan Undangundang nomor 1 tahun 1974 (Studi di desa Gegerung Kec. Lingsar Lombok Barat), [Online] Di kutip dari (https://www.google.com/search?ei=1YL oWvD-

M4zyvASptY7wDg\&q=jurnal+ilmiyah+ analisis+perkawinan+anak+di+bawah $+\mathrm{u}$ mur+tinjauan+hukum+islam+dan+undan g+undang+no+1+di+desa+gegerung+kec amatan+lingsar+barat+lombok+oleh+ary a+ananta+wijaya\&oq=jurnal+ilmiyah $+a n$ alisis+perkawinan+anak+di+bawah+umu $\underline{\mathrm{r}+\text { tinjauan+hukum+islam+dan+undang }+\mathrm{u}}$ $\underline{\text { ndang+no+1+di+desa+gegerung+kecama }}$ tan+lingsar+barat+lombok+oleh+arya+an anta+wijaya\&gs $1=$ psyab.3...128648.287652.0.287988.212.144. $0.0 .0 .0 .4512 .18183 .2-$ 10j10j3j1j0j1j0j2.27.0...0...1c.1.64.psy- ab..191.8.2901...0j0i131k1j0i67k1j0i10k 1j0i22i30k1j0i22i10i30k1j0i13k1j33i160 k1j33i21k1.0.uJNr1_Ai6Ns) di akses pada tanggal 11 April 2018

Hadiyan Edwin. Jurnal. Membangun Kesadaran Masyarakat Mengenai Tradisi Perkawinan Di Bawah Umur Terhadap Anak. Di kutip dari (http://jurnal.uinbanten.ac.id/index.php/j sga/article/view/176/178) diakses pada tanggal 10 seotember 2018

Maria Ulfa Binda. Jurnal. Pemahaman Masyarakat Tentang Perkawinan DiUsia Anak-anak di Tinjau Dari Pasal 26 Ayat 1 Huruf C Undang-undang NO 23 Tahun 2002 Tentang Perlindungan Anak ( Studi kasus di kelurahan kedungkandang kecamatan kedungkandang kota malang). Dikutip dari (https://www.google.com/search?q=jurna 1+pemahaman+masyarakat+tentang+pern ikahan+di+usia+anakanak+studi+kasus+di+kelurahan+kedung kandang+kabupaten+malang+oleh++bind

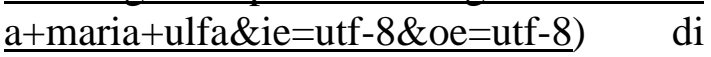
akses pada tanggal 12 April 2018.

Syahuri Taufiqurrohman. 2013. Legislasi Hukum Perkawinan di Indonesia. Jakarta: Fajar Interpratama Mandiri

Undang-undang Perkawinan Nomor 1 Tahun 1974

Undang-undang Perkawinan Nomor 1 Tahun 1974 tentang Perkawinan dan Kompilasi Hukum Islam

Undang-undang Republik Indonesia Nomor 23 Tahun 2014 Tentang Perubahan Atas Undang-undang Nomor 23 Tahun 2002 Tentang Perlindungan Anak 
ZulfaMardiyatusSholeha 